Peter Zieme

\title{
The First Leaf of an Old Uyghur 觀無量壽經 Guanwuliangshoujing Translation
}

DOI $10.17816 /$ wmo34964

Abstract: The paper discusses the 觀無量壽經 Guanwuliangshoujing (T. 365) in Old Uyghur. It is an important text of the Pure Land Buddhism known only in its original Chinese text. Several separated fragments in Old Uyghur are known. One fragment of the Turfan Collection in Berlin (U 1499) can be joined with a leaf of the Serindia Collection of the IOM (SI 1748). The result is presented here. One of its interesting differences is the list of 15 Bodhisattvas of which only Mañjuśrī is given by name in the Chinese original.

Key words: 觀無量壽經 Guanwuliangshoujing, Pure Land Buddhism, first leaf, Uyghur Buddhism

The paper discusses the 觀無量壽經 Guanwuliangshoujing (T. 365) in Old Uyghur. It is an important text of the Pure Land Buddhism known only in its original Chinese text. The sheet U 1499 presented here was edited in 1985 by K. Kudara and P. Zieme. ${ }^{1}$ At that time, however, it was not recognized that the join of two fragments of the glassed text was erroneous. Now, after knowing of SI 1748 from the IOM collection it became possible to make a correct join. The smaller fragment of U 1499 must be placed after a lacuna of two lines. SI 1748 has to be joined directly with the larger fragment of U 1499 on the left side, ${ }^{2}$ while the smaller fragment of U 1499 forms the lower part of lines 8-11. This new situation does not change K. Kudara's fundamental assessment that this sheet represents a rather free

(C) Peter Zieme, Berlin-Brandenburgische Akademie der Wissenschaften, Berlin, 2020

${ }^{1}$ ZiEME and KuDARA 1985, 21-23.

${ }^{2}$ Under the same number SI 1748 there is another (or two?) small fragment with remainders of 5 lines that may belong to the manuscript, but a clear localization in T. 365 is not possible. 
rendering of the Chinese text by the Uighur translator. ${ }^{3}$ Since the Berlin fragment U 1499 bears the old signature T I $\alpha$, one can assume that the leaf SI 1748 was also found at the same ruin $\alpha$ in Kočo (Gaochang).

The first 13 lines of the recto side which comprise the title are written in red ink. The pustaka hole interrupts lines 7 to 9, which corresponds to the usual pattern of a wide pustaka leaf. On the left margin of the verso side only the first two letters are present, but they can probably be emended to ba[štınkı bir ptr] "Fi[rst (juan), first leaf]".

Since in most cases the first leaf of a Buddhist work is missing, it is appropriate to publish the joined leaf here separately. Apart from the composition in alliterating quatrains, ${ }^{4}$ only a few leaves have been found and published so far. One of them is a very early edition of a well-preserved sheet acquired by the Otani expedition and published by Z. Tachibana. ${ }^{5}$ Later, K. Kudara presented an improved edition. ${ }^{6}$ At the same time another sheet from the Berlin collection was edited. ${ }^{7}$ Recently, A. Mirkamal has identified a further fragment, probably from a different manuscript, in the Beijing National Library. It will be edited in a forthcoming paper together with a Berlin parallel, which could be assembled from two fragments. ${ }^{8}$

\section{Text in transcription ${ }^{9}$}

SI $1748($ Kr. II 8/1) + U 1499 (T I $\alpha)$

(recto)

01 [na]mo but .. namo d(a)rm .. namo say ..

02 [tü]käl bilgä bilig-lig t(ä)yri t(ä)yri

T.XII.365.0340c27 佛説

03 [-si] burhan y(a)rlıkamıš kedin yıjak

04 [art]ukrak mäni-lig uluš-ta y(a)rl[1]

05 [-kayur ü]lgülänčs[i]z uzun özlüg 觀無量壽佛

$06\left[\right.$ yaš $\left.\quad{ }^{10}\right]-1[1] \mathrm{g}$ y(a)rlıkanču

\footnotetext{
${ }^{3}$ ZIEME and KuDARA 1985, 23.

${ }^{4}$ ZIEME and KUDARA 1985.

${ }^{5}$ TACHIBANA 1912.

${ }^{6}$ KUdARA 1979.

${ }^{7}$ ZIEME 1982.

${ }^{8}$ MiRKAMAL and ZiEME.

${ }^{9}$ On the right side the Chinese equivalents are given according to the Taishō text 365 .

${ }^{10}$ It is not clear which word fits into the lacuna.
} 
07 [-čı köyül] $\quad$-lüg abita

$08 \mathrm{t}($ ä)pri burh[an] $\quad-1 \mathrm{~g}$.. alt1-1

09 y(i)g(i)rmi tü[r] -lüg kolulamak

10 -1g sakınč-lar [ü]zä öyü sakınu

11 tokuz türlüg tugum-1n tugmak

12 -1g ukıtmak atl(1)g nom bitig bir

13 tägzinč ::....

14 ančulayu ärür mänin äšidmiš-im ..

15 ymä bir üdün on küčlüg ulug

經

…:

0340029 我聞如是

一時佛住

16 y(a)rlıkančučı könül-lüg .. tükäl-1

17 bilgä bilig-lig atı kötrülmiš ..

18 t(ä)yri t(ä)yrisi burhan .. kutlug

19 ülüglüg račagr(a)h atl(1)g ulug el

20 uluš-ka yakın .. grtrakut atl(1)g

王舍城

21 tag-ta y(a)rlıkayur ärti ..

.. ol

22 üdün bar ärür-lär .. üč tümän

者闍崛山中

23 iki min bodis(a)t(a)v-lar .. m(a)havast 五十人俱]菩薩三萬二 ${ }^{0341 a 02} 千$

24 [-lar] olar ymä [ $]^{11}$

(verso)

ba[štınkı bir ptr]

01 -lar tep tesär .. mančuširi nom han1 文殊師利法王子。而爲上首

02 ögüki bodis(a)t(a)v m(a)havaste samantabad]re]

03 [t]olpı tözün bodis(a)t(a)v aryavaloki[teš]

04 -var 1duk yertinčüg körmäk-d[ä]

05 ärksinmäk-lig bodis(a)t(a)v [m(a)ha]

06 -astamaprapt[e] ulu[g küč]l[lär]

07 [-kä] tägmiš

[ ]

08 baiš-a-ča -[ra]č otačı

09 -lar eligi han1 ${ }^{12} \quad$ bo[di]s(a)t(a)v ....

10 baiš-a-ča samutga[ta] otačı-lar-r

11 baštı1ı bodis(a)t(a)v [..] maitri ädgü-ü 12 ögli köyül-lüg bodis(a)t(a)v ....

${ }^{11}$ Although it was not possible to find a correct solution for emending this line, it is clear that here the question about the names is needed.

12 The emendation to hanı is unclear as only ' $y$ can be seen. 
13 kök kalık agılıkı bodis(a)t(a)v ..

14 vžir agilık bodis(a)t(a)v .. lenhu-a

15 čäčäk agılıkı bodis(a)t(a)v .. yagız yer

16 agılıkı bodis(a)t(a)v .. sukančı ad

17 mangal bodis(a)t(a)v .. tıdıgıg köžigig

18 tarkarmıš bodis(a)t(a)v .. uzatı yerinü

19 -däči bodis(a)t(a)v uzatı katıglanur

20 bodis(a)t(a)v .. muntada ulatı ulug bod[is(a)t(a)v]

21 -lar ädräm-kä tükäl-lig alku nom

22 -larıg tıdıgsız bilmäk ukmak

23 -ta ärksinmäklig burhan-lar ul[u]šın

24 [-ta ] titgäli [tar]k[argalı $]^{13}$

\section{Translation $^{14}$}

[Introductory Formula]

Namo buddhāya, namo dharmāya, namạ̣ saṃghāya!

[Title]

The sūtra scripture preached by the perfectly wise god Buddha called "The teaching of the nine kinds of births while thinking and contemplating in thoughts of the 16 meditations on the divine Buddha Amitābha, who is in the Western Extreme Blessed Land, is of immeasurable longevity and merciful [sense]", one book (juan).

[Time and place]

Thus I have heard. Once the the great merciful, perfectly wise god Buddha possessing the ten powers, whose name is sublime, stayed on the mountain named Gṛdhrakūtạ ${ }^{15}$ near the happy, blessed great empire named Rājagṛha.

\footnotetext{
${ }^{13}$ It remains unclear how this line can be emended.

${ }^{14}$ Translation of the Chinese text: "Thus have I heard. At one time the Buddha was staying on the Vulture Peak in Rājagrha with a great assembly of twelve hundred and fifty monks. He was also accompanied by thirty-two thousand bodhisattvas led by Mañjuśrī, the Dharma Prince." (INAGAKI 1994, 317)

${ }^{15}$ The Old Uyghur text follows the Chinese when a transcription of the Sanskrit name is used. An Old Uyghur translation occurs in the text of the Buyan ävirmäk to the Altun Yaruk Sudur: kara kuš säyirlig arlg ol grtirakut tagta "on the mountain with the vulture peak, i.e. [the pronoun $o l$ has here this function] Mount Gṛdhrakūṭa" (Suv. 682/22-23). This occurrence not recorded in UWN II.1 shows that its meaning is not only "Wald".
} 


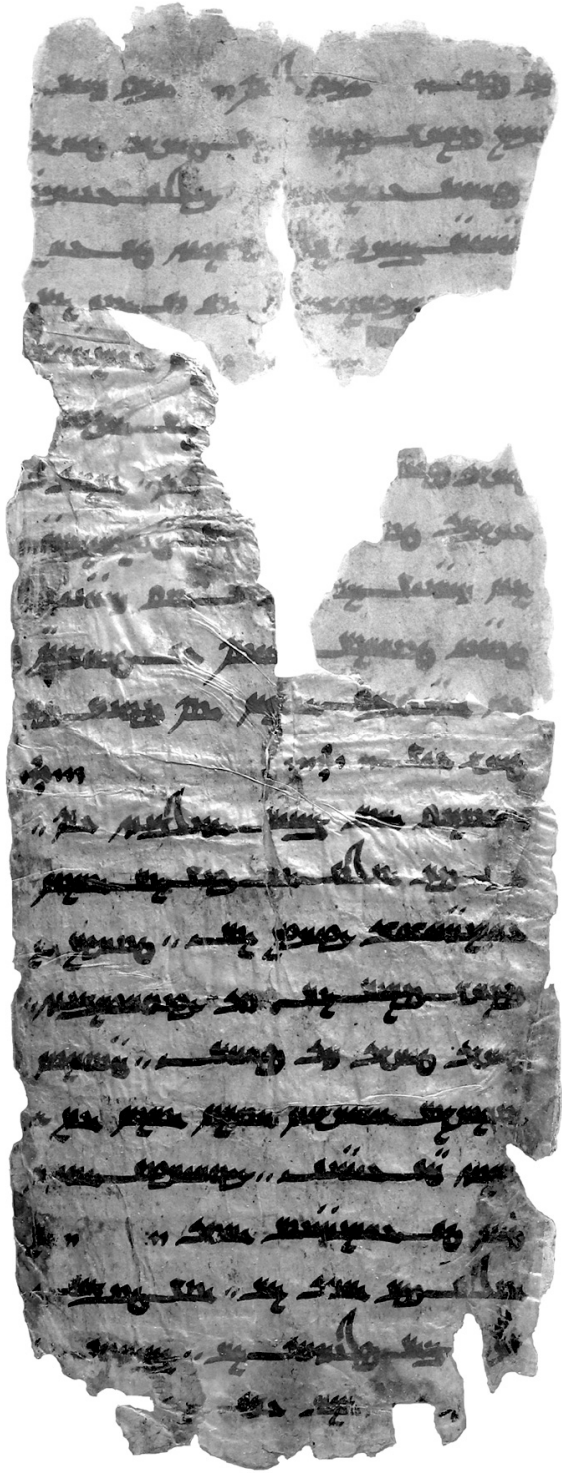

$\mathrm{U} 1499+$ SI 1748 recto
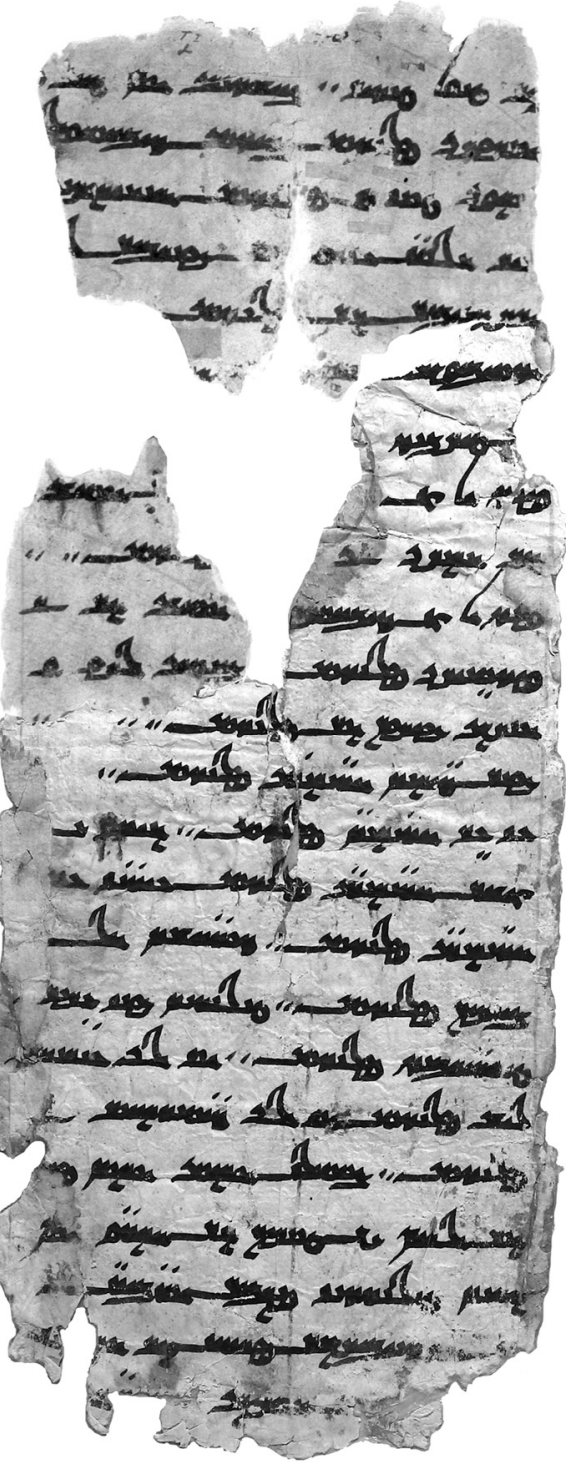

U $1499+$ SI 1748 verso 
[Bodhisattvas]

At this time there are 32000 Bodhisattvas Mahāsattvas. What are their names? (They are) the great bodhisattvas who are perfect in virtue and strength, in unlimited understanding and knowledge, starting with [1] Bodhisattva Mahāsattva Mañjuśrī, Beloved of the Dharma, [2] Bodhisattva Samantabhadra, the Noblest One, [3] Bodhisattva Ārya Avalokiteśvara, holy and powerful to see the world, [4] Bodhisattva [Mahā]sthāmaprāpta, the one who has achieved great power, [5] Bodhisattva Bhaișajyarāja, the King of doctors, [6] Bodhisattva Bhaișajyasamudgata, the leader of the doctors, [7] Bodhisattva Maitreya, with a mind of good will, [8] Bodhisattva Sky Firmament Treasure, [9] Bodhisattva Vajra Treasure, [10] Bodhisattva Lotus Flower Treasure, [11] Bodhisattva Earth Store, [12] Bodhisattva Glorious Happiness, [13] Bodhisattva Remover of obstacles, [14] Bodhisattva Ever wailing, [15] Bodhisattva Constantly striving (...)

\section{Comments on the Bodhisattva names}

The list of 15 Bodhisattvas ${ }^{16}$ given here is not known from other contexts. Usually Bodhisattva groups consist of 2, 3, 4, 8, 16, 25, 53 and more names. ${ }^{17}$ At the beginning of the Larger Sukhāvatīvy ühasütra ${ }^{18}$ there is first the triad of the Bodhisattvas [here no.2] Samantabhadra, [here no. 1] Mañjuśrī and [here no. 7] Maitreya. ${ }^{19}$ These three names are also among the Bodhisattvas listed here, but in a different order. The remaining 12 of the present list of 15 Bodhisattvas are otherwise well-known Bodhisattvas, but not known from another compilation. All these circumstances support Kudara's suggestion ${ }^{20}$ that an Old Uighur Buddhist had compiled a list by himself. Possibly the Uyghur author wanted to provide a more vivid picture of the setting against the simple statement of 32000 Bodhisattvas surrounding the Buddha in the Chinese text. The position of Mañjuśri who is the only one mentioned by name in the Chinese text as the first Bodhisattva is kept also here.

\footnotetext{
${ }^{16}$ The Chinese introduction to the Larger Sukhāvatīvyūha-sūtra has a list of 16 Bodhisattvas, but the Uyghur version of Dunhuang (see MOTH 2 and Kudara 1995) has only 15 as here, but the names are different. Cp. KUDARA and ZIEME 1997, 78.

${ }^{17}$ It is to be mentioned that most of the Bodhisattvas play their respective roles in the Buddhist texts, many of them are referred to in the study of KUO 1994.

${ }^{18}$ KUDARA 1995. First edited in MOTH 2.

${ }^{19}$ INAGAKI 1994, 228.

${ }^{20}$ ZIEME and KUDARA 1985, 23.
} 
Mañjuśrī [1] who has the epithet 法王子 “the Dharma Prince". In Old Uyghur this epithet is translated mostly by nom ögüki "Beloved of the Dharma" which is, of course, not an exact rendering of "prince". Mañjuśri is one of the most prominent Bodhisattvas and thus well-known in Old Uyghur. $^{21}$

The Bodhisattvas Ārya Avalokiteśvara [3] and Mahāsthāmaprāpta [4] form the two Bodhisattvas who surround the Buddha Amitābha the chief Buddha of the Pure Land Buddhism.

The Bodhisattva Bhaișajyarāja [5] and the Bodhisattva Bhaișajyasamudgata [6] are well-known from the Healing sūtras.

Other famous Bodhisattvas are Ākāśagarbha [8], Vajragabha [9] and Padmagarbha [10]. The Bodhisattva Kșitigarbha [11] is an important figure as the guide in hells known from apocryphal texts as well as from art objects. The Bodhisattva * Sumangala ${ }^{22}[12]$ is less prominent. The Bodhisattva Sarvanivārana-vișkambhin $[13]^{23}$ is not often encountered in Old Uyghur texts. The last Bodhisattva Nityodyukta "Constantly Striving" [15] 常精進 Chang jingjin is a Bodhisattva known e.g. from the Lotus Sūtra ${ }^{24}$. The Uyghur name uzatı katıglanur = 常精進 Chang jingjin occurs in the Kšanti kılguluk nom as uzatı katıglandač $\iota^{25}$.

A special comment should be given for No. 14: uzatı yerinüdäči bodis(a)t(a)v, the translation of the Bodhisattva Sadāprarudita who holds a prominent position in Old Uyghur. The chapters Dharmodgata and Sadāprarudita of the Prajñāpāramitā sūtra were transformed into a long poem in alliterating verses. ${ }^{26}$ In the Kšanti kilguluk nom the same Bodhisattva occurs $^{27}$. His Chinese name 薩陀波輪菩薩 ${ }^{28}$ satuobolun is a transcription of Sadāprarudita or, as J. Wilkens writes, Sadāpralāpa "ever chattering, or bewailing, name of a Bodhisattva, some say who wept while searching for truth" ${ }^{29}$. The Chinese translation of the name is 常啼 changti “Ever wailing".

${ }^{21}$ ZIEME 2020.

${ }^{22} \mathrm{Cp}$. the Bodhisattva name Mangala 吉祥菩薩 jixiang (DDB). As the name 秒吉祥菩薩 miaojixiang which could be reconstructed as *Sumangala is another name of Mañjuśrī (DDB), it cannot be meant here. A similar case can be seen in the name of a Buddha Mangala who is known also as Sumangala, cp. CicuzzA 2011, 185.

${ }^{23}$ KuO 1994, 158: 除蓋障 Chu gai zhang, DDB “Remover of Hindrances Bodhisattva”.

${ }^{24}$ DDB.

${ }^{25}$ BT 25, p. 432a.

${ }^{26}$ Recently re-edited in Nuri 2015.

${ }^{27}$ BT 25, p. 432b.

${ }^{28}$ BT 25, 3737, 4157. T.1909.965bb06 and 967b12-13.

${ }^{29} \mathrm{SH} 468 \mathrm{~b}$. 
Accordingly, in both texts this name was translated into Old Uyghur as uzat yeriyüdäč $i^{30}$ "ever wailing", while in other texts, the above mentioned poem as well as in a Baȟ̌s $\ddot{O} g$ disi, the name was given in the transliterated Sanskrit form sadapira-urudita ${ }^{31}$ or sada-pira-rudite ${ }^{32}$. There are many studies about this Bodhisattva because he is regarded as protector of the Mahāprajñāpāramitā and as a hero searching for the truth. The Chinese name appears also in abbreviated forms ${ }^{33}$. One example is 波侖 bolun in the Biography of Xuanzang ${ }^{34}$ transcribed in HT VIII 605 palun $^{35}$.

\section{References}

BT $25 \quad$ Wilkens.

DDB Digital Dictionary of Buddhism (Charles Muller).

HT VIII Röhrborn.

IOM Institute of Oriental Manuscripts of the Russian Academy of Sciences, St. Petersburg.

MOTH Hamilton.

OTWF Erdal.

SH Soothill \& Hodous.

T. Taishō Shinshū Daizōkyō.

UWN Röhrborn.

Cicuzza, Claudio 2011: A Mirror Reflecting the Entire World. The Pāli Buddhapādamañgala or "Auspicious Signs on the Buddha's Feet", Bangkok and Lumbini.

ERDAL, Marcel 1991: Old Turkic Word Formation, Wiesbaden, Harrassowitz Verlag.

FrankENHAUSER, Uwe 1995: Cien-Biographie VIII, Wiesbaden, Harrassowitz Verlag.

Hamilton, James Russell: Manuscrits ouïgours du $\mathrm{IX}^{\mathrm{e}}-\mathrm{X}^{\mathrm{e}}$ siècle de Touen-Houang, Paris 1986 (Peeters).

InAGaKi Hisao 1994: The Three Pure Land Sutras. A Study and Translation from Chinese, Kyoto 1994. Nagata Bunshodo.

KARA, György 1968: Az Aranyfény-szutra. Suvarṇaprabhāsottamasūtrendrarāja, Budapest (Mongol Nyelvemléktár XIII).

KITSUDŌ Kōichi 2017: New Light on the Huayan jing in Old Uighur from the Krotkov Collection and Yoshikawa Photographs, in: Essays on the Manuscripts written in Central Asian Languages in the Otani Collection. Buddhism, Manichaeism, and Christianity.

\footnotetext{
${ }^{30}$ For the verb yeriyü- cp. OTWF 476, DTS 263a and several other examples. The Mongol Altan Gerel (KARA, 88) has nasuda uyilayči "unceasingly wailing".

${ }^{31}$ Nuri 2015.

32 ÖLMEZ 1998, line 59.

${ }^{33}$ DDB.

${ }^{34}$ FranKenHaUSER 1995, 79 (220).

${ }^{35}$ HT VIII 605, quoted by J. Wilkens, BT 25, Anm. zu 3737.
} 
Ed. by T. Irisawa and K. Kitsudo, Kyoto 2017 (Ryukoku University Silk Road Studies 6), Research Center for Buddhist Culture, Ryukoku University, 107-153.

KuDARA, Kōgi. Guan-Jing - Critique of a Uigur fragment of the Guan wu-liang-shou jing — in: Studies in Buddhism 35 (1979), 33-56.

KuDARA, Kōgi. An Uigur Fragment of the Larger Sukhāvatīvyūha-Sūtra from the Dunhuang Cave 17, in: Ryūkoku kiyō 17 (1995), 1-16.

KudAra, Kōgi and Zieme, Peter. Two New Fragments of the Larger Sukhāvatīvyūhasūtra in Uigur, in: Studies On the Inner Asian Languages XII (1997), 73-82.

Kuo, Liying. Confession et Contrition dans le bouddhisme chinois du $\mathrm{V}^{\mathrm{e}}$ au $\mathrm{X}^{\mathrm{e}}$ siècle. Paris 1994 (Publications de l'École française d'Extrême Orient, Monographies no. 170).

Mirkamal, Aydar \& Zieme, Peter. Further Fragments of the Old Uighur Translation of the 佛說觀無量壽經 Foshuo Guanwuliangshoujing (in preparation).

NuRI, Raziye. Alliterative Prajñāpāramitā Texts in Old Uyghur Preserved in Paris, Shanghai 2015 (Shanghai Chinese Classics Publishing House).

ÖlmEz, Mehmet. Tibet Budizme Ait Eski Uygurca Bahşı Ögdisi, in: Bahşı Ögdisi. Festschrift für Klaus Röhrborn anläßlich seines 60. Geburtstags, Freiburg-Istanbul 1998, 261-293.

RÖHRBORN, Klaus. Die alttürkische Xuanzang-Biographie VIII, Wiesbaden 1996 (Harrassowitz Verlag).

RÖHRBORN, Klaus. Uigurisches Wörterbuch. Sprachmaterial der vorislamischen türkischen Texte aus Zentralasien - Neubearbeitung-II. Nomina — Pronomina - Partikeln, Band 1: a - asvik, Stuttgart 2015 (Franz Steiner Verlag).

Soothill, William Edward and Hodous, Lewis. A Dictionary of Chinese Buddhist Terms with Sanskrit and English Equivalents and a Sanskrit-Pali Index, Taipei 1976 (Reprinted by Ch'eng Wen Publishing Company).

TACHIBANA, Zuichō. Uiguru yaku no Kammuryōjukyō, in: Niraku sōsho 1 (1912), 21-41.

Wilkens, Jens. Das Buch von der Sündentilgung. Edition des alttürkisch-buddhistischen Kšanti Kilguluk Nom Bitig, Turnhout 2007 (Berliner Turfantexte XXV).

ZIEME, Peter. A new fragment of the Uigur Guanwuliangshoujing. In: Ryūkoku Daigaku Bukkyōbunka Kenkyūsho kiyō. Bulletin of the Institute of Buddhist Cultural Studies, Ryūkoku University. Special Issue 20, Kyoto 1982, 20-29.

ZIEME, Peter. Wutaishan and Mañjuśrī in Old Uigur Buddhism. In: The Transnational Cult of Mount Wutai. Historical and Comparative Perspectives, Brill 2020 (Studies on East Asian Religions, Vol. 2 ed. by S. Andrews, J. Chen, K. Guang), (forthcoming).

ZIEME, Peter and Kudara, Kōgi. Guanwuliangshoujing in Uigur, Kyoto 1985. Nagata Bunshōdō. 